\title{
PENGARUH MODEL PEMBELAJARAN KOOPERATIF TIPE NHT TERHADAP AKTIVITAS BELAJAR DAN PRESTASI BELAJAR TEKNIK DASAR PASSING SEPAK BOLA KELAS XI SMA NEGERI 1 BANGLI
}

\author{
M. A. K. Wardana, I Wayan Santyasa, I Made Tegeh \\ Program Studi Teknologi Pembelajaran, Program Pascasarjana \\ Universitas Pendidikan Ganesha \\ Singaraja, Indonesia
}

e-mail:\{kusuma.wardana, wayan.santyasa, made.tegeh\}@pasca.undiksha.ac.id

\begin{abstract}
Abstrak
Tujuan penelitian ini adalah mendeskripsikan perbedaan aktivitas belajar ( $A B)$ dan prestasi belajar (PB) teknik dasar passing sepak bola antara siswa yang belajar dengan model pembelajaran kooperatif tipe Number Head Together (NHT) dan model pembelajaran konvensional (PK). Penelitian ini menggunakan rancangan nonequivalence pretest-posttest control group design. Populasinya adalah 4 kelas siswa kelas XI SMA Negeri 1 Bangli. Sampel sebanyak 2 kelas ditentukan dengan teknik group random sampling, demikian pula dalam menentukan kelompok eksperimen dan kelompok kontrol. Instruemen penelitian adalah pedoman pengamatan, baik untuk mengumpulkan aktivitas belajar maupun prestasi belajar. Analisis data menggunakan MANCOVA. Setelah perlakuan dikontrol dengan aktivitas dan prestasi belajar awal, hasil penelitian menunjukkan hal-hal sebagai berikut. (1) Terdapat perbedaan $\mathrm{AB}$ dan $\mathrm{PB}$ teknik dasar pasing sepak bola antara siswa yang belajar dengan model pembelajaran NHT dan model PK. (2) Terdapat perbedaan AB teknik dasar passing sepak bola antara siswa yang belajar dengan model pembelajaran NHT dan model PK. (3) Terdapat perbedaan PB teknik dasar passing sepak bola antara siswa yang belajar dengan model pembelajaran NHT dan model PK.Kecenderungan aktifitas belajar siswa kelompok NHT Kooperatif dapat dikategorikan tinggi. Siswa yang belajar dengan model NHT secara konsisten menunjukkan $\mathrm{AB}$ dan $\mathrm{PB}$ lebih tinggi dibandingkan dengan siswa yang belajar dengan model PK.
\end{abstract}

Kata kunci: model pembelajaran NHT, aktivitas belajar, prestasi belajar, teknik dasar passing sepak bola.

\begin{abstract}
The purpose of this study is to describe differences in learning activities $(A B)$ and achievement (PB) basic techniques of passing football between students learning with cooperative learning model Number Head Together (NHT) and conventional learning models (PK). This study uses nonequivalence design pretest-posttest control group design. Its population is the fourth grade class XI student of SMAN 1 Bangli. Samples were second class group determined by random sampling techniques, as well as in determining the experimental group and the control group. Instruemen research is observational guidelines, both to gather learning activities and learning achievements. Analysis of data using MANCOVA. After the treatment is controlled by activity and early learning achievement, the results showed the following matters. (1) There are differences $A B$ and $P B$ pasing basic techniques of football among the students who study learning model NHT and PK models. (2) There is a difference AB basic techniques of passing football between students who learn learning model NHT and PK models. (3) There are differences PB basic techniques of passing football between students who learn learning model NHT and PK models. The tendency of students' learning activities NHT cooperative group can be categorized as high. Students who study with NHT consistently showed AB and PB is higher than students who studied with PK models.
\end{abstract}

Keywords: NHT, learning activities, academic achievement,basic techniques of passing football. 


\section{PENDAHULUAN}

Pendidikan jasmani, olahraga dan kesehatan (penjasorkes) merupakan bagian integral dari pendidikan secara keseluruhan, bertujuan untuk mengembangkan aspek kebugaran jasmani, keterampilan gerak, keterampilan berpikir kritis, keterampilan sosial, penalaran, setabilitas emosional, tindakan moral, aspek pola hidup sehat, dan pengenalan lingkungan bersih melalui aktivitas jasmani, olahraga dan kesehatan terpilih yang direncanakan secara sistematis dalam rangka mencapai tujuan pendidikan nasional (Depdiknas 2006: 163). Rendahnya prestasi belajar siswa tentu tidak sepenuhnya disebabkan oleh faktor luar seperti kesibukan guru, keadaan rumah tangga, lingkungan dan lain lain. Rendahnya prestasi belajar siswa dipengaruhi oleh beberapa faktor dari dalam guru itu sendiri seperti kemauan menyiapkan bahan yang lebih baik, termasuk kemauan guru itu sendiri untuk menerapkan metode-metode ajar yang telah didapat di bangku kuliah. Selain itu guru juga kurang mampu untuk dapat mengembangkan keterampilan mengajar yang dapat menarik perhatian siswa dan merangsang siswa untuk belajar. Dari semua uraian di atas dapat diketahui halhal yang perlu dalam upaya meningkatkan prestasi belajar siswa seperti penguasaan metode metode ajar; penguasaan modelmodel pembelajaran; penguasaan teoriteori belajar; penguasaan teknik-teknik tertentu; penguasaan peran, fungsi serta kegunaan mata pelajaran. Berdasarkan pengamatan penulis dilapangan kenyataannya, sebagian besar guru yang mengalami masalah dalam menjalankan profesinya dan ia tidak dapat menjalankan tugasnya dengan baik (secara alamiah). Akibatnya ketika mutu proses dan hasil belajar atau pendidikan rendah, guru selalu melempar tanggung jawab kepada pihak lain, misalnya anak kurang aktivitas, ke orang tua, lingkungan dan sebagainya. Padahal salah satu masalah yang dihadapi dunia pendidikan kita adalah masalah lemahnya proses pembelajaran dan rendahnya hasil belajar yang dicapai.

Dalam proses pembelajaran, anak kurang didorong untuk mengembangkan kemampuan berpikir. Proses pembelajaran di dalam kelas diarahkan kepada kemampuan untuk menghafal informasi, otak anak dipaksa untuk mengingat dan menimbun berbagai informasi tanpa dituntut untuk memahami informasi yang diingatnya itu untuk menghubungkannya dalam kehidupan sehari-hari. Ketika anak didik kita lulus dari sekolah, mereka pintar secara teoritis, tetapi mereka miskin aplikasi. Oleh karena itu pemilihan model pembelajaran yang tepat akan mampu menyesuaikan keadaan atau situasi di dalam proses pembelajaran dengan menyesuaikan karakteristik siswa di dalam proses belajar pembelajaran (Santyasa, 2012). Cuplikan di atas menunjukkan betapa pentingnya model untuk diterapkan dalam mencapai suatu keberhasilan, begitu pula terhadap kegunaan model-model pembelajaran. Sebelum ada model, dikembangkan terlebih dahulu teori yang mendasari model tersebut, sehingga boleh dikatakan bahwa teori lebih luas daripada model. Modelmodel, baik model fisika, model-model komputer, model-model matematika, semua mempunyai sifat "jika - maka", dan modelmodel ini terkait sekali pada teori. Kalau permasalahan seperti tersebut di atas dibiarkan dan berlanjut terus, maka lulusan kita sebagai generasi penerus bangsa akan sulit bersaing dengan lulusan dari berbagai negara lain. Lulusan yang diperlukan tidak sekedar mampu mengingat dan memahami informasi, tetapi juga mampu menerapkannya dalam kehidupan seharihari.

Sehubungan dengan kondisi di atas untuk meningkatkan kualitas proses dan prestasi belajar passing sepak bola serta untuk meningkatkan aktivitas belajar siswa perlu guru melakukan pembelajaran dengan model-model pembelajaran yang inovatif, Salah satu model pembelajaran kooperatif yang dapat diterapkan di SMA adalah model pembelajaran kooperatif tipe NHT. Berbagai temuan penelitian terdahulu menunjukkan bahwa model pembelajaran 
kooperatif, termasuk model NHT membantu guru dan siswa dalam mencapai tujuan pembelajaran. Penelitian yang dilakukan oleh Parna (2015) menemukan bahwa model pembelajaran kooperatif mempunyai efektivitas yang cukup tinggi dalam pembelajaran Penjaskesrek dan dapat meningkatkan hasil belajar yang cukup tinggi dalam hubungannya dengan penguasaan materi, sikap, nilai moral dan ketrampilan sosial siswa. Oleh sebab itu, pengaruh model NHT terhadap aktivitas dan prestasi belajar permainan sepak bola sangat menarik untuk diteliti.

Berdasarkan latar belakang tersebut, dan dengan memperhitungkan aktivitas dan prestasi belaajar awal sebagai kontrol, tujuan penelitian ini adalah sebagai berikut. (1) Mendeskrepsikan aktivitas dan prestasi belajar antara siswa yang belajar dengan model pembelajaran NHT dan model pembelajaran konvensional.

Mendeskripsikan perbedaan aktivitas belajar teknik dasar passing sepak bola antara siswa yang belajar dengan model pembelajaran NHT dan model pembelajaran konvensional. (3) Mendeskripsikan perbedaan prestasi belajar teknik dasar passing sepak bola antara siswa yang belajar dengan model pembelajaran NHT dan model pembelajaran konvensional.

\section{METODE PENELITIAN}

Penelitian ini menggunakan eksperimen semu (quasi) dengan rancangan nonequivalence preetestposttest control group design Penelitian ini melibatkan 4 kelas siswa sebagai populasi dan 2 kelas sampel. Penentuan 2 kelas sampel dan menentukan kelompok eksperimen dan kelompok kontrol dilakukan secara random.

Penelitian ini mengkaji satu variabel bebass dan dua variabel terikat. Variabel bebasnya adalah model pembelajaran, yang dibedakan atas model NHT dan model konvensioal. Variabel terikatnya adalah aktivitas belajar dan prestasi belajar teknik dasar passing sepak bola. Data kedua variabel terikat tersebut dikumpulkan dengan pedoman observasi yang telah tervalidasi.

Pedoman pengamatan aktivitas belajar siswa terdiri dari 12 butir, rentangan skor idealnya 0-39. Skor mentah siswa dikonversi ke sekala 0-100. Pedoman pengamatan prestasi belajar siswa terdiri dari 30 butir bersifat dikotomis, sehingga rentangan skor idealnya 0-30. Skor menta prestasi belajar siswa dikonversi ke skala 0 100.

Data dianalisis secara deskriptif dan teknik MANCOVA. Analisis deskriptif digunakan untuk mendeskripsikan nilai ratarata dan simpangan baku variabel aktivitas dan prestasi belajar teknik dasar passing sepak bola. MANCOVA dipakai untuk menguji hipotesis penelitian.

\section{HASIL DAN PEMBAHASAN}

\section{HASIL PENELITIAN}

Secara umum, hasil penelitian dapat dipaparkan pada Tabel 01.

Tabel 01. Rekapitulasi Hasil Analisis Desktiptif Data Aktivitas belajar dan Prestasi Belajar

\begin{tabular}{lcccccccc}
\hline & \multicolumn{3}{c}{ Aktivitas Belajar } & \multicolumn{3}{c}{ Prestasi Belajar } \\
\hline \multicolumn{1}{c}{ Deskripsi } & \multicolumn{3}{c}{ Model NHT } & $\begin{array}{c}\text { Model } \\
\text { Pembelajaran } \\
\text { Konvensional }\end{array}$ & Model NHT & \multicolumn{2}{c}{$\begin{array}{c}\text { Model } \\
\text { Pembelajaran } \\
\text { Konvensional }\end{array}$} \\
\hline & Pretest & Posttest & Pretest & Posttest & Pretest & Posttest & Pretest & Posttest \\
\hline $\begin{array}{l}\text { Jumlah } \\
\text { Siswa (N) }\end{array}$ & 30 & 30 & 30 & 30 & 30 & 30 & 30 & 30 \\
\hline $\begin{array}{l}\text { Rata-Rata } \\
(\bar{X})\end{array}$ & 55,20 & 81,30 & 53,13 & 68,93 & 49,90 & 72,93 & 53,00 & 64,07 \\
\hline $\begin{array}{l}\text { Simpangan } \\
\text { Baku (SD) }\end{array}$ & 7,62 & 7,60 & 6,44 & 8,50 & 13,34 & 9,51 & 12,06 & 10,81 \\
\hline
\end{tabular}


Jurnal Teknologi Pembelajaran Indonesia

ISSN: 2615-2797(Print) | ISSN: 2614-2015 (Online) Volume 8 Nomor 3 Tahun 2018

\begin{tabular}{lcccccccc}
\hline Modus & 48 & 78 & 52 & 78 & 35 & 68 & 48 & 58 \\
\hline Median & 55 & 80 & 52 & 68 & 49 & 72 & 53 & 64 \\
\hline $\begin{array}{l}\text { Nilai } \\
\text { Maksimum }\end{array}$ & 68 & 95 & 66 & 92 & 73 & 90 & 78 & 85 \\
\hline $\begin{array}{l}\text { Nilai } \\
\text { Minimum }\end{array}$ & 48 & 68 & 42 & 56 & 30 & 53 & 32 & 48 \\
\hline Rentangan & 22 & 27 & 24 & 36 & 43 & 37 & 46 & 37 \\
\hline
\end{tabular}

Berdasarkan Tabel 01 dapat disajikan deskripsi-deskripsi seperti berikut. Pada kelompok NHT, hasil pretest menunjukkan nilai rata-rata $M=55,20$; $S D$ $=7,62$ dengan katagori cukup, sedangkan hasil posttest $M=81,30$; SD 7,60 dengan katagori tinggi. Dibandingkan dengan model pembelajaran konvensional, tampak bahwa nilai pretest aktivitas belajar adalah $\mathrm{M}=$ 53,13; SD 6,44 dengan katagori cukup, sedangkan pada posttest $M=69,93$; $S D$ 8,50 dengan kategori cukup. Berdasarkan perbandigan dari dua model pembelajaran tersebut, tampak bahwa model pembelajaran NHT secara deskriptif lebih baik dari model pembelajran konvensional dalam pencapaian aktivitas belajar.
Pada variabel prestasi belajar ditemukan pada kelompok NHT menunjukan hasil nilai rata-rata $M=49,90$; SD 13,34 dengan katagori kurang, sedangkan hasil posttest $M=72,92$; $S D$ 9,51 dengan katagori tinggi. Nilai rata-rata ppretest prestasi belajar siswa pada model pembelajaran konvensional adalah $\mathrm{M}=$ 53,00; SD 12,06 dengan katagori kurang, sedangkan nilai posttest $M=64,07$; $S D$ 10,81 dengan katagori cukup. Ternyata model pembelajaran NHT secara deskriptif lebih baik dibandingkan dengan model pembelajran konvensional dalam pencapaian prestasi belajar.

\section{Tabel 02 Hasil Uji Multivariat dengan SPSS}

\begin{tabular}{|c|c|c|c|c|c|c|}
\hline & Effect & Value & $F$ & $\begin{array}{c}\text { Hypothesi } \\
s d f\end{array}$ & Error $d f$ & Sig. \\
\hline Intercept & Pillai's Trace & 0,556 & $34,487^{a}$ & 2,000 & $34,487^{a}$ & 0,000 \\
\hline & Wilks' Lambda & 0,444 & $34,487^{a}$ & 2,000 & $34,487^{a}$ & 0,000 \\
\hline & Hotelling's Trace & 1,254 & $34,487^{a}$ & 2,000 & $34,487^{a}$ & 0,000 \\
\hline & Roy's Largest Root & 1,254 & $34,487^{a}$ & 2,000 & $34,487^{a}$ & 0,000 \\
\hline Prates & Pillai's Trace & 0,052 & $1,496^{a}$ & 2,000 & $34,487^{a}$ & 0,000 \\
\hline $\begin{array}{l}\text { Aktivitas } \\
\text { Belaiar }\end{array}$ & Wilks' Lambda & 0,948 & $1,496^{a}$ & 2,000 & $34,487^{a}$ & 0,000 \\
\hline & Hotelling's Trace & 0,054 & $1,496^{a}$ & 2,000 & $34,487^{a}$ & 0,000 \\
\hline & Roy's Largest Root & 0,054 & $1,496^{a}$ & 2,000 & $34,487^{a}$ & 0,000 \\
\hline Prates & Pillai's Trace & 0,468 & $24,176^{a}$ & 2,000 & $34,487^{a}$ & 0,000 \\
\hline Prestasi & Wilks' Lambda & 0,532 & $24,176^{a}$ & 2,000 & $34,487^{a}$ & 0,000 \\
\hline & Hotelling's Trace & 0,879 & $24,176^{a}$ & 2,000 & $34,487^{a}$ & 0,000 \\
\hline & Roy's Largest Root & 0,879 & $24,176^{a}$ & 2,000 & $34,487^{a}$ & 0,000 \\
\hline Model & Pillai's Trace & 0,470 & $24,351^{a}$ & 2,000 & $34,487^{a}$ & 0,000 \\
\hline $\begin{array}{l}\text { Pembela- } \\
\text { jaran }\end{array}$ & Wilks' Lambda & 0,530 & $24,351^{a}$ & 2,000 & $34,487^{a}$ & 0,000 \\
\hline & Hotelling's Trace & 0,885 & $24,351^{a}$ & 2,000 & $34,487^{a}$ & 0,000 \\
\hline & Roy's Largest Root & 0,885 & $34,351^{a}$ & 2,000 & $34,487^{a}$ & 0,000 \\
\hline
\end{tabular}

Hasil analisis seperti pada Tabel 02 menunjukan bahwa nilai-nilai statistik untuk Pillai's Trace, Wilks' Lambda, Hotelling's
Trace, dan Roy's Largest Root pada sumber pengaru prates aktivitas belajar dan pratest prestasi belajar adalah $\mathrm{F}=34,487$ 
dengan sig $=0,001$. Hasil ini menunjukan $\mathrm{Ho}_{1}$ ditolak. Dengan kata lain kovariabel aktivitas dan prestasi belajar awal berpengaruh singnifikan baik terhadap aktivitas belajar maupun prestasi belajar

Menurut sumber pengaruh model pembelajaran terhadap aktivitas belajar dan prestasi belajar (Tabel 02), ditemukan nilainilai statistik $F=34,487$ dengan sig 0,001. Hasil ini menunjukan bahwa $\mathrm{Ha}_{1}$ ditolak. dengan kata lain, terdapat pengaruh model pembelajaran terhadap aktivitas dan prestasi belajar.

Tabel 0.3 Ringkasan Pengujian Pengaruh Antar Subjek

\begin{tabular}{|c|c|c|c|c|c|c|}
\hline Source & Dependent Variable & $\begin{array}{l}\text { Type III Sum } \\
\text { of Squares }\end{array}$ & df & $\begin{array}{l}\text { Mean } \\
\text { Square }\end{array}$ & $\mathrm{F}$ & Sig. \\
\hline \multirow[t]{2}{*}{ Corrected Model } & Posttes_AktivitasBelajar & $2596,758^{a}$ & 3 & 865,586 & 13,971 & 0,000 \\
\hline & Posttes_PreastasiBelajar & $3002,651^{\mathrm{b}}$ & 3 & 1000,884 & 20,322 & 0,000 \\
\hline \multirow[t]{2}{*}{ Intercept } & Posttes_AktivitasBelajar & 2872,636 & 1 & 2872,636 & 46,367 & 0,000 \\
\hline & Posttes_PreastasiBelajar & 1167,090 & 1 & 1167,090 & 23,697 & 0,000 \\
\hline \multirow{2}{*}{$\begin{array}{l}\text { Prates_Aktivitas } \\
\text { Belajar }\end{array}$} & Posttes_AktivitasBelajar & 185,439 & 1 & 185,439 & 2,993 & 0,089 \\
\hline & Posttes_PreastasiBelajar & 2,566 & 1 & 2,566 & 0,052 & 0,820 \\
\hline \multirow{2}{*}{$\begin{array}{l}\text { Prates_Prestasi } \\
\text { Belajar }\end{array}$} & Posttes_AktivitasBelajar & 74,758 & 1 & 74,758 & 1,207 & 0,277 \\
\hline & Posttes_PreastasiBelajar & 2367,065 & 1 & 2367,065 & 48,061 & 0,000 \\
\hline \multirow{2}{*}{$\begin{array}{l}\text { Model_Pembelaja } \\
\text { ran }\end{array}$} & Posttes_AktivitasBelajar & 1940,000 & 1 & 1940,000 & 31,314 & 0,000 \\
\hline & Posttes_PreastasiBelajar & 894,192 & 1 & 894,192 & 18,156 & 0,000 \\
\hline \multirow[t]{2}{*}{ Error } & Posttes_AktivitasBelajar & 3469,425 & 56 & 61,954 & & \\
\hline & Posttes_PreastasiBelajar & 2758,082 & 56 & 49,251 & & \\
\hline \multirow[t]{2}{*}{ Total } & Posttes_AktivitasBelajar & 344617,000 & 60 & & & \\
\hline & Posttes_PreastasiBelajar & 297804,000 & 60 & & & \\
\hline \multirow[t]{2}{*}{ Corrected Total } & Posttes_AktivitasBelajar & 6066,183 & 59 & & & \\
\hline & Posttes_PreastasiBelajar & 5760,733 & 59 & & & \\
\hline
\end{tabular}

Berdasarkan hasil analisis yang ditunjukan pada Tabel 03, dapat disajikan temuantemuan sebagai berikut.

Berdasarkan sumber pengaruh pratest aktivitas belajar, ditemukan nilai statistik $F=2,993$ dengan angka sig. = 0,089 untuk variabel aktivitas belajar, dan $\mathrm{F}$ $=0,052$ dengan Angka sig $=0,820$ untuk variabel prestasi belajar. Ternyata angkaangka sig tersebut lebih besar dari 0,05, sehingga kovariabel aktivitas awal tidak berpengaruh terhadap aktivitas belajar dan prestasi belajar.

Dilihat dari sumber pengaruh pratest prestasi belajar ditemukan $\mathrm{F}=1,277$ dengan angka sig $=0,277$ untuk variabel aktivitas belajar, dan $F=48,061$ dengan angka sig $=0,001$ untuk variabel prestasi belajar. Hasil tersebut menunjukkan bahwa kovariabl prestasi belajar awal tidak berpengaruh secara signifikan terhadap aktivitas belajar, tetapi berpengaruh terhadap prestasi belajar.

Hipotesis kedua $\mathrm{Ha}_{2}$ menyatakan bahwa "Terdapat perbedaan aktivitas belajar teknik dasar passing sepak bola antara siswa yang belajar dengan model pembelajaran kooperatif tipe NHT dan model pembelajaran konvensional, setelah 
pembelajaran di kontrol dengan aktivitas dan prestasi awal.

Hipotesis $\mathrm{Ha}_{2}$ tersebut diuji dengan tests of between-subjects effects (Tabel 03) dengan kriteria $\mathrm{H}_{02}$ ditolak apabila taraf signifikansi $F$ lebih kecil dari 0,05. Berdasarkan Tabel 03 diperoleh niali statistik $F=31,314$ dengan angka sig = 0,001 yang ternyata lebih kecil dari 0,05 , sehingga $\mathrm{HO}_{2}$ "ditolak" dan $\mathrm{Ha}_{1}$ "diterima". Jadi, terdapat perbedaan yang signifikan aktivitas belajar teknik dasar passing sepak bola antara siswa yang belajar dengan menggunakan model Numbered Head Together (NHT) dengan siswa yang belajar dengan menggunakan model pembelajaran konvensional. Nilai aktivitas belajar siswa yang belajar dengan model $\mathrm{NHT}(\mathrm{M}=81,30 ; \mathrm{SD}=7,60)$ lebih tinggi dibandingkan dengan model pembelajaran konvensional $(\mathrm{M}=68,93$; $\mathrm{SD}=8,50$ ).

Hipotesis ketiga $\mathrm{H}_{\mathrm{a} 3}$ menyatakan bahwa "terdapat perbedaan prestasi belajar

\section{PEMBAHASAN}

Berdasarkan hasil analisis uji hipotesis 1, dapat disimpulkan bahwa terdapat perbedaan yang signifikan aktivitas belajar dan prestasi belajar siswa secara bersama-sama antara siswa yang belajar dengan model Numbered Head Together (NHT) dengan siswa yang belajar dengan model pembelajaran konvensional. Nilai rata-rata di kelompok NHT pada aktivitas belajar dan prestasi belajar lebih tinggi dibandingkan dengan kelompok pembelajaran konvensional. Data keempat nilai rata-rata tersebut terdapat perbedaan secara signifikan sehingga dapat disimpulkan bahwa model pembelajaran berpengaruh signifikan terhadap aktivitas belajar dan prestasi belajar secara bersama-sama. Model Numbered Head Together (NHT) selain dapat meningkatkan aktivitas belajar siswa, juga diikuti oleh peningkatan prestasi belajar siswa.

$$
\text { Suasana pembelajaran dengan }
$$

menggunakan model kooperatif berlangsung secara dinamis dimana siswa bukan lagi sebagai obyek pembelajaran semata-mata melainkan bisa juga berperan teknik dasar passing sepak bola antara siswa yang belajar dengan model pembelajaran NHT dan model pembelajaran konvensional.

Hipotesis $\mathrm{H}_{\mathrm{a} 3}$ tersebut diuji dengan tests of between-subjects effects (Tabel 03) dengan kriteria $\mathrm{H}_{03}$ ditolak apabila taraf signifikansi $F$ lebih kecil dari 0,05. Berdasarkan Tabel 03 diperoleh angka statistik $F=18,156$ dengan nilai sig $=0,001$ yang lebih kecil dari 0,05 ), sehingga $\mathrm{HO}_{3}$ "ditolak" dan $\mathrm{Ha}_{3}$ "diterima". Jadi, terdapat perbedaan yang signifikan prestasi belajar teknik dasar passing sepak bola antara siswa yang belajar dengan menggunakan model Numbered Head Together (NHT) dengan siswa yang belajar dengan menggunakan model pembelajaran konvensional. Nilai prestasi belajar siswa yang belajar dengan model NHT $(M=72,93 ; S D=9,51)$ lebih tinggi dibandingkan dengan nilai prestasi belajar pada model pembelajaran konvensional $(M=64,07 ; 10,81)$.

sebagai tutor bagi siswa lainnya. Hal ini terjadi karena setiap anggota kelompok belajar memiliki dua tanggung jawab yang harus dia lakukan, yaitu mempelajari dan memahami materi serta membantu teman belajarnya untuk mampu memahami dan mengerti sebagaimana yang ada pada dirinya. Melalui pembelajaran model kooperatif diharapkan menghasilkan beberapa nilai lebih dalam hubungannya dengan pengembangan potensi diri siswa dan antisipasi positif dalam upaya pembentukan warga negara yang baik, yaitu ; (1) meningkatkan rasa tanggung jawab individu, (2) menumbuhkan ketergantungan yang bersifat positif, (3) memungkinkan terbinanya hubungan yang bersifat terbuka, (4) memungkinkan pengembangan keterampilan keterampilan sosial secara optimal, dan (5) melatih siswa untuk hidup bermasyarakat.

Pada hasil uji hipotesis 2 ditemukan bahwa terdapat perbedaan aktivitas belajar yang signifikan antara kelompok siswa yang belajar menggunakan model Numbered Head Together (NHT)dengan kelompok siswa yang belajar menggunakan model 
pembelajaran konvensional. Nilai rata-rata aktivitas belajar siswa yang belajar dengan model Numbered Head Together (NHT) lebih tinggi dan berbeda secara signifikan dengan siswa yang belajar dengan model pembelajaran langsung. Nilai rata-rata tersebut berbeda secara signifikan setelah diuji dengan teknik MANCOVA dengan melibatkan hasil pre-test aktivitas belajar sebagai kovariat. Perbedaan aktivitas belajar siswa disebabkan oleh beberapa faktor yang terkait dengan model pembelajaran NHT seperti pengetahuan awal dan pembelajaran yang berorientasi pada tujuan.

Aktivitas belajar siswa pada pelajaran Pendidikan Penjaskesrek dipengaruhi oleh berbagai faktor, seperti: interaksi yang terjadi di luar kelas, model pembelajaran dan media yang digunakan guru, sarana dan prasarana yang tersedia, kemampuan siswa. Ini berarti model pembelajaran dapat mempengaruhi aktivitas belajar siswa pada pelajaran Pendidikan Penjaskesrek. Model pembelajaran yang sesuai dengan karakteristik materi ajar dan sistuasi luar kelas memungkinkan dapat menumbuhkan aktivitas belajar siswa.

Diketahui bahwa antara pembelajaran kooperatif NHT dan pembelajaran konvensional dalam pembelajaran menunjukkan penekanan esensi yang berbeda. Pada pembelajaran kooperatif $\mathrm{NHT}$, aktivitas pembelajaran cenderung berpusat pada siswa, siswa dituntut untuk aktif berinisiatif dan berpartisipasi dalam keseluruhan proses pembelajaran, sedangkan guru diharapkan untuk lebih berfungsi sebagai fasilitator, motivator dan koordinator kegiatan pembelajaran. Sebaiknya pada pembelajaran dengan pembelajaran konvensional, aktivitas pembelajaran cenderung berpusat pada guru, guru merupakan inisiator dan pemegang kendali dalam seluruh aktivitas pembelajaran, siswa tinggal mengikuti apa yang telah dirancang dan diprogramkan oleh guru.

Hasil uji hipotesis 3 ditemukan bahwa terdapat perbedaan prestasi belajar secara signifikan antara siswa yang belajar mengikuti model Numbered Head Together
(NHT) dengan siswa yang belajar mengikuti model pembelajaran Konvensional. Perbedaan ini terlihat dari nilai rata-rata prestasi belajar pada post-test di kelompok NHT lebih besar dibandingkan dengan kelompok pembelajaran konvensional. Kedua nilai tersebut berbeda secara signifikan setelah diuji dengan teknik MANCOVA dengan memasukkan nilai pretest prestasi belajar sebagai kovariat. Perbedaan prestasi belajar siswa disebabkan oleh beberapa faktor yang terkait dengan model pembelajaran NHT seperti pengetahuan awal dan pembelajaran yang berorientasi pada tujuan.

Hasil penelitian ini sesuai dengan hasil yang diperoleh Arta, Sntyasa, dan Tegeh (2014), Munawaroh (20150, dan Supartini, Marhaeni, dan Candiasa (2015). Sebagai salah satu ciri pembelajaran kooperatif tipe NHT adalah menggunakan sistem pengelompokan kecil heterogen antara 3-5 orang yang mempunyai latar belakang kemampuan akademik dan jenis kelamin yang berbeda (Santyasa, 2012). Sistem penilaian dilakukan terhadap kelompok (Santyasa, 2014). Setiap kelompok akan memperoleh (reward), jika kelompok mampu menunjukkan prestasi yang dipersyaratkan, dengan demikian, setiap anggota kelompok akan mempunyai ketergantungan positif. Ketergantungan semacam itulah yang selanjutnya akan memunculkan tanggung jawab individu terhadap kelompok dan ketrampilan interpersonal dari setiap anggota kelompok. Setiap individu akan saling membantu, mereka akan mempunyai motivasi untuk keberhasilan kelompok, sehingga masingmasing individu memiliki kesempatan yang sama untuk memberikan kontribusi demi keberhasilan kelompok. Teknik-teknik tersebut tidak terdapat dalam model pembelajaran konvensional. Hal inilah yang menyebabkan model NHT secara komparatif lebih unggul dibandingkan dengan model konvensional dalam pencapaian aktivitas dan prestasi belajar.

\section{SIMPULAN DAN SARAN}

Berdasarkan uraian di atas, dapat disimpulkan bahwa model pembelajaran 
berpengaruh terhadap aktivitas belajar dan prestasi belajar. Secara lebih rinci simpulan dapat diuraikan sebagai berikut.

Pertama, terdapat perbedaan yang signifikan aktivitas belajar dan prestasi belajar antara siswa yang belajar dengan model NHT dan siswa yang belajar dengan model pembelajaran konvensional. Aktivitas belajar dan prestasi belajar siswa siswa yang belajar dengan NHT lebih tinggi dibandingkan dengan yang belajar dengan pembelajaran konvensional.

Kedua, terdapat perbedaan yang signifikan aktivitas belajar antara siswa yang belajar dengan model NHT dan siswa yang belajar dengan model pembelajaran konvensional. Aktivitas belajar pada siswa yang belajar dengan model NHT lebih tinggi dibandingkan dengan siswa yang mengikuti model pembelajaran konvensional.

Ketiga, terdapat perbedaan yang signifikan prestasi belajar antara siswa yang belajar dengan model NHT dan siswa yang belajar dengan model pembelajaran konvensional. Prestasi belajar siswa pada kelompok NHT lebih tinggi dibandingkan dengan siswa pada kelompok pembelajaran konvensional.

\subsection{Saran}

Berdadarkan hasil penelitian yang dipaparkan pada bab IV bahwa model NHT lebih baik dibandingkan dengan model pembelajaran konvensional dalam pencapaian aktivitas belajar dan prestasi belajar siswa dalam pembelajaran Penjaskesrek. Berdasarkan hasil penelitian ini, maka dapat diajukan saran-saran sebagai berikut.

Pertama, dalam proses pembelajaran khususnya aktivitas belajar dan prestasi belajar Penjaskesrek di SMA, para guru dapat menerapkan model NHT sebagai salah satu model pembelajaran alternatif. Untuk memperoleh hasil yang optimal, dalam penerapan model NHT guru hendaknya menyiapkan perangkat pembelajaran sampai pada tahap evaluasi. Guru dapat mengunakan teknologi dan informasi untuk menunjang penerapan model NHT di kelas. Jika persiapan pembelajaran sudah dilakukan dengan baik, tujuan pembelajaran akan lebih mudah tercapai secara optimal. Jika guru memahami karakteristik dan sintaks model pembelajaran yang akan digunakan maka proses pembelajarannya akan berjalan dengan baik sesuai dengan apa yang sudah ditargetkan sebelumnya.

Kedua, pembelajaran dengan model NHT dapat meningkatkan aktivitas belajar dan prestasi belajar siswa, maka dari itu siswa hendaknya mampu mengembangkan potensinya dalam belajar secara optimal. Siswa harus selalu berperan aktif dalam proses pembelajaran, dan peran guru sangat penting sebagai fasilitator dalam mengembangkan potensi siswa.

Ketiga, penelitian ini memiliki suatu kelemahan yaitu hanya mengangkat topik tentang aktivitas belajar dan prestasi belajar Penjaskesrek saja. Hal ini sesebabkan oleh keterbatasan kemampuan dan waktu yang dimiliki peneliti.

\section{DAFTAR RUJUKAN}

Al-Ghazo, A. 2015. The effect of SQ3R and semantic mapping modeles on reading comprehension learning among jordanian university students. International Journal of English and Education. 4(3). 92-106. Tersedia pada http://ijee.org/ yahoo site admin/assets/docs/9. 19010631.pdf. Diakses 16 Februari 2016.

Chuenchaichon, Y. 2011. Impact of intensive reading on the written performance of Thai University EFL writers. In D. S. Giannoni and C. Ciarlo (ed.) University of Reading Language Studies Working Papers(3): 3-14. Tersedia pada https://www.reading .ac.uk/web/FILES/english-languageand-literature/ell-language 2 Chuenchaichon vol 3.pdf. Diakses 27 Oktober 2016

Apriani, F., Dantes, N., \& Jampel, I N. 2015. Pengaruh metode pembelajaran 
projek berbantuan media Jaws terhadap motivasi belajar dan prestasi belajar TIK siswa Smalb Slb A Negeri Denpasar. E-Journal Terdapat pada pasca.undiksha.ac.id/e-

journal/index.php/. Diakses 23 januari 2016.

Parna, I K., Dantes, N., \& Marhaeni, A. A. I. N. 2015. Pengaruh model pembelajaran kooperatif tipe STAD terhadap motivasi berprestasi dan hasil belajar IPA siswa kelas V SD Gugus VII Kecamatan Kubu Tahun Pelajaran 2014/2015. EJournal. Terdapat pada pasca.undiksha.ac.id/ejournal/index.php/. Diakses 23 januari 2016.

Supartini, I G. A. M., Marhaeni, A. A. I. N., \& Candiasa, I. M. 2015. Pengaruh model pembelajaran kooperatif tipe NHT berbantuan alat peraga sederhana terhadap motivasi berprestasi dan hasil belajar matematika. E-Journal. Terdapat pada pasca.undiksha.ac.id/ejournal/index.php/. Diakses 23 januari 2016.

Artha, I K. A,. Santyasa, I W., \& Tegeh, I M. 2014. Pengaruh model pembelajaran kooperatif dan bakat kinestetik terhadap prestasi belajar teknik dasar passing bola volly pada siswa kelas X SMA Negeri 1 Busungbiu. E-Journal. Terdapat pada pasca.undiksha.ac.id/ejournal/index.php/. Diakses 23 januari 2016.

Santyasa, I W. 2012. Pembelajaran inovatif. Singaraja: Undiksha Press.

Sertel, A. 2015. The effect of cooperative learning on students' achievement and views on the science and technology course. International Electronic Journal of Elementary Education. Terdapat pada www.iejee.com. Diakses 23 januari 2016.

Sarioglan, M. \& Cevizkaya, G. 2015. Applicability of cooperative learning model in gastronomy education. Terdapat pada http://dergipark.ulakbim.gov.tr/jttr/. Diakses 23 januari 2016.

Gani, A., Safitri, R., Habibati., \& Saminan, N. F. 2016. The Study Of High School students's scientific attitudes on learning heat and temperature with cooperative inquiry labs model. E-Journal. Terdapat pada www.ntcu.edu.tw/chin/. Diakses 23 januari 2016

Munawaroh. 2015. The comparative study between the cooperative learning model of numbered heads together (NHT) and student team achievement division (STAD) To the learning achievement in social subject. Terdapat pada www.iosriournals.org. Diakses 23 januari 2016.

Keshavarz, S. M., Shahrokhi, M., \& Talebi Nejad, M. R. 2014. The Effect Of Cooperative Learning Techniques On Promoting Writing Skill Of Iranian Efl Learners. Terdapat pada www.ijllalw.org. Diakses 23 januari 2016.

Sulisworo, D. \& Suryani, F. 2014. The effect of cooperative learning, motivation and information technology literacy to achievement. Terdapat pada http://dx.doi.org/10.5296/ijld.v4i2.4 908. Diakses 23 januari 2016

Razak. F. 2016. The effect of cooperative learning on mathematics learning outcomes viewed from students' learning motivation. E-Journal. Terdapat pada http://journals.ums.ac.id/index.php/ iramathedu Diakses 23 januari 2016.

Astawan, K. W., Santyasa, I W., \& Tegeh, I. M. 2013. Pengembangan Modul Berbasis Model Pembelajaran Kooperatif Tipe Group Investigation Pada Mata Pelajaran Server Jaringan Di Smk Ti Bali Global Singaraja. E-Journal. Terdapat pada pasca.undiksha.ac.id/ejournal/index. php/.diakses23 Januari 2016. 